\title{
PENGGUNAAN MODEL INDEKS TUNGGAL DALAM MENILAI RESIKO DAN RETURN SAHAM UNTUK PILIHAN BERINVESTASI
}

\author{
Anny Widiasmara \\ Putri Widyasari \\ Universitas PGRI Madiun \\ widyasariputri17@gmail.com
}

\begin{abstract}
The purpose of this study was to assess the risk and return stock that could be an option to invest by using single index model Compass 100 on the IDX in 2010-2014. This type of research used in this research is descriptive quantitative approach. Samples taken as many as 44 companies of the index Compass 100. The results showed that of the 44 samples selected companies, there were 13 companies that have an optimal return and minimal risk to the proportion of each stock: UNVR of 0.2372039\%, ANTM of 0.0057649\%, BMTR of $0.14997799 \%$, GGRM of $0.1226567 \%$, MNCN of $0.1571756 \%$, JSMR of $0.2749157 \%$, KLBF of $0.0493033 \%$, CPIN at $98.771899 \%$, CTRA of $0.1009368 \%$, GJTL of $0.0607808 \%$, MEDC of $0.0209188 \%$, KIJA of $0.0253161 \%$, LPKR 0.0231518\%. Based on the portfolio has been formed on the calculation of portfolio return of $4.74 \%$ and the risk of a portfolio of $0.0019683 \%$.
\end{abstract}

Keywords : Singe Index Model, Optimal Portfolio, Investment Options

\section{PENDAHULUAN}

Dewasa ini, pasar modal di Indonesia semakin menunjukkan perkembangan yang positif. Perkembangan positif ini tidak lepas dari campur tangan pemerintah yang memberikan banyak kebijakan guna mendorong perkembangan pasar modal di Indonesia, antara lain kebijakan yang menyederhanakan proses penerbitan sekuritas bagi perusahaan yang ingin go public serta membuka kesempatan yang luas bagi investor asing dengan adanya saham untuk tunjuk dan membuka kesempatan bagi perusahaan baru yang belum memiliki laba untuk mencari modal di Bursa Efek Indonesia (Ibrahim, 2009).

Perkembangan pasar modal yang baik ini juga menarik minat masyarakat untuk menginvestasikan sebagian dana mereka dengan menjadi investor. Investor memperjualbelikan sekuritas di pasar modal. Salah satu sekuritas yang ramai diminati masyarakat adalah saham. Saham bersifat high risk high return, yaitu memiliki resiko yang tinggi namun pengembaliannya juga tinggi. Mengingat risiko yang melekat pada investasi saham lebih tinggi dari pada investasi pada perbankan, return yang diharapkan juga lebih tinggi (Suharli, 2005). Investor harus cermat mengambil langkah untuk meminimalisir resiko saham sehingga return bisa optimal sesuai harapan, serta menentukan level jual dan beli agar peluang untuk mendapatkan keuntungan bisa optimal.

Cara meminimalisir resiko tersebut adalah dengan tidak menginvestasikan dana hanya untuk membeli saham pada satu perusahaan saja. Jika hanya menempatkan dana 
untuk membeli saham pada satu perusahaan saja, bila perusahaan itu gulung tikar, maka investor pasti terkena dampaknya langsung. Hendaknya dana investasi dialokasikan untuk membeli saham pada beberapa perusahaan yang berbeda atau biasa disebut diversifikasi, sesuai proporsi resiko dan return yang telah dianalisa terlebih dahulu guna mengantisipsi hal-hal yang tidak diinginkan. Hasil diversifikasi ini berupa portofolio. Menurut Hartono (2014:343) para investor dihadapkan dengan banyaknya kombinasi saham dalam portofolio yang akhirnya harus mengambil keputusan portofolio mana yang akan dipilih oleh investor.

Salah satu model yang bisa dipakai dalam menghitung nilai resiko dan return saham adalah model indeks tunggal. Linda Ratnasari (2015) dan Triharjono (2013) memilih model indeks tunggal karena model indeks tunggal merupakan penyederhanaan dari model-model optimalisasi portofolio investasi lain seperti Model Markowitz dan Capital Asset Pricing Model (CAPM). Murhadi (2014) membandingkan model indeks tunggal dengan model $\mathrm{Z}$, hasilnya model indeks tunggal memberikan resiko yang lebih kecil dari pada penggunaan metode Z. Model indeks tunggal dikembangkan oleh William Sharpe (1963) dimana dapat juga digunakan untuk menghitung return ekspektasi dan resiko portofolio. Model indeks tunggal didasarkan pada pengamatan harga dari suatu sekuritas berfluktuasi searah dengan indeks harga pasar (Hartono, 2014:407).

Proses pemilihan 100 saham yang masuk dalam penghitungan indeks Kompas 100 ini mempertimbangkan faktor likuiditas, kapitalisasi pasar dan kinerja fundamental dari saham-saham tersebut. Kriteria Pemilihan Saham Indeks Kompas100 adalah dengan mempertimbangkan faktor-faktor:

1. Tercatat di BEI minimal 3 bulan

2. Aktivitas transaksi di pasar reguler yaitu nilai, volume dan frekuensi transaksi

3. Jumlah hari perdagangan di pasar reguler

4. Kapitalisasi pasar pada periode waktu tertentu

5. Faktor-faktor fundamental dan pola perdagangan

Saham-saham yang temasuk dalam indeks Kompas 100 ini selain memiliki likuiditas yang tinggi, serta nilai kapitalisasi pasar yang besar, juga merupakan saham-saham yang memiliki fundamental dan kinerja yang baik. Saham-saham ini diperkirakan mewakili sekitar 70$80 \%$ dari total $\mathrm{Rp} 1.582$ triliun nilai kapitalisasi pasar seluruh saham yang tercatat di BEI, maka investor bisa melihat kecenderungan arah pergerakan indeks dengan mengamati pergerakan indeks Kompas 100 (www.wikipedia.org ). Namun walaupun begitu masih terdapat ketidakpastian terhadap return yang diterima oleh investor yang nampak dari fluktuasi return Indeks Kompas 100. Oleh sebab itu, Peneliti memilih Kompas 100 untuk dijadikan sebagai subjek penelitian.

\section{KAJIAN PUSTAKA}

Pasar modal adalah tempat atau sarana bertemunya antara permintaan dan penawaran atas instrumen keuangan jangka panjang, umumnya lebih dari 1 (satu) tahun (Samsul, 2006:43). Pasar modal merupakan pasar untuk memperjualbelikan sekuritas, 
sedangkan tempat terjadinya jual beli sekuritas disebut bursa efek (Tandelilin, 2010 : 26).

Saham adalah tanda bukti memiliki perusahaan dimana pemiliknya disebut juga sebagai pemegang saham (shareholder atau stockholder) (Samsul, 2006 :45). Hak kepemilikannya dapat dijual dalam bentuk saham (stock) (Hartono, 2014:169).

IHSG merupakan indeks gabungan dari seluruh jenis saham yang tercatat di Bursa Efek Indonesia (BEI). IHSG diterbitkan oleh Bursa Efek. IHSG berubah setiap hari karena (1) perubahan harga pasar yang terjadi setiap hari dan (2) adanya saham tambahan (Samsul, 2006 : 185).

Return saham adalah pendapatan yang dinyatakan dalam presentase dari modal awal investasi. Pendapatan investasi dalam saham meliputi keuntungan jual beli saham, dimana jika untung disebut capital gain dan jika rugi disebut capital loss. Disamping capital gain, investor juga akan menerima deviden tunai setiap tahunnya (Samsul, 2006 : 291). Return merupakan hasil yang diperoleh dari investasi, dapat berupa return realisasi dan return ekspektasi. Return Realisasi yaitu adalah return yang sudah terjadi dan dihitung berdasarkan data historis. Return realisasi digunakan sebagai salah satu pengukur kinerja perusahaan dan sebagai dasar penentuan resiko serta return ekspektasi di masa depan (Hartono, 2014: 263). Sedangkan return ekspektasi adalah return yang diharapkan untuk diperoleh investor di masa depan. Return ekspektasi sifatnya belum terjadi (Hartono, 2014: 263)

Resiko dalam investasi juga perlu dihitung karena return dan resiko tidak bisa dipisahkan. Hubungan return dan resiko adalah semakin besar resiko yang harus ditanggung, semakin besar return yang harus dikompensasikan (Hartono, 2014: 285). Tandelilin (2010: 102) dalam Hamdani (2015) mengungkapkan bahwa resiko adalah kemungkinan perbedaan antara return harapan dan return aktual yang diterima. Resiko yang tidak terkait dengan pasar secara keseluruhan disebut resiko tidak sistematis (unsystematic risk), sedangkan yang terkait dengan perubahan keseluruhan pasar disebut resiko sistematis (systematic risk)

Portofolio merupakan investasi dalam berbagai instrumen keuangan (diversifikasi). Portofolio dimaksudkan untuk mengurangi resiko investasi dengan cara menyebarkan dana ke berbagai aset yang berbeda, sehingga jika satu aset menderita kerugian sementara aset lainnya tidak menderita kerugian, maka nilai investasi kita tidak hilang semua. (Samsul, 2006 : 301).

Menurut Tandelilin (2010: 157) dalam Hamdani (2015) bahwa portofolio efisien adalah portofolio dengan return tinggi pada resiko tertentu atau pada return tertentu portofolio dengan rendah resiko. Sedangkan portofolio optimal adalah portofolio pilihan investor dari berbagai portofolio efisien. Menurut Hartono (2014: 367), portofolio optimal adalah portofolio dengan kombinasi terbaik. Portofolio efisien belum tentu portofolio optimal meskipun portofolio optimal adalah bagian dari portofolio efisien (Hartono, 2014: 365). Menentukan portofolio optimal didasarkan dengan angka yang dapat menentukan apakah sekuritas dapat masuk portofolio optimal atau tidak, dimana 
angka tersebut adalah rasio antara ekses return dengan beta (excess return to beta ratio (ERBi)). ERBi adalah selisih return ekspektasi dengan return bebas resiko. Portofolio optimal berisi aktiva dengan nilai rasio ERB yang tinggi. Aktiva dengan ERB rendah dikeluarkan dari kategori optimal. Penentuan tinggi atau rendahnya ERB ini berdasarkan titik pembatas cut off point $\left(\mathrm{C}^{*}\right)$. Syarat portofolio dikatakan optimal bila ERBi $\geq \mathrm{C}^{*}$ (Hartono, 2014:429-432).

Model indeks tunggal didasarkan pada pengamatan harga dari suatu sekuritas berfluktuasi searah dengan indeks harga pasar. Secara umum, saham mengalami kenaikan jika indeks harga saham naik, begitu sebaliknya jika indeks harga saham turun, kebanyakan saham mengalami penurunan harga. Hal ini menggambarkan bahwa return-return dari sekuritas mungkin berkorelasi karena adanya reaksi umum (common response) terhadap perubahan nilai pasar (Hartono, 2014: 407). Model indeks tunggal dapat dirumuskan sebagai berikut:

$$
R i=\alpha i+\beta i . R M+e i
$$

Sumber: Hartono (2014: 409)

Keterangan:

$\mathrm{Ri}$ : return sekuritas ke- i,

$\alpha \mathrm{i}$ : nilai ekspektasian dari return sekuritas yang independen terhadap return pasar

$\beta \mathrm{i}$ : beta yang merupakan koefesien yang mengukur perubahan $\mathrm{Ri}$ akibat dari perubahan RM,

$\mathrm{RM}$ : tingkat return dari indeks pasar, juga merupakan suatu variabel acak

ei : kesalahan residu yang merupakan variabel acak dengan nilai ekspektasinya sama dengan nol atau $\mathrm{E}(\mathrm{ei})=$ 0 (Hartono, 2014:408-409)

\section{METODE}

Jenis penelitian yang digunakan adalah penelitian deskriptif, yaitu penelitian yang dilakukan untuk mengetahui nilai variabel mandiri, baik satu variabel atau lebih (independen) tanpa membuat perbandingan atau menghubungkan dengan variabel yang lain (Sugiyono, 2009: 56). Pendekatan yang digunakan adalah pendekatan kuantitatif karena data utamanya adalah angka.

Teknik yang digunakan dalam pengambilan sampel adalah sampling purposive. Tujuannya disini untuk mendapatkan perusahaan yang benar-benar konsisten selama periode penelitian (2010-2014).

Definisi operasional yang digunakan :

1. Closing price saham-saham kompas 100 yang terpilih periode 2010-2014

Harga penutupan (closing price) diperlukan untuk mencari return realisasi dan return ekspektasi

2. Closing price IHSG Kompas 100 periode 2010-2014

IHSG mewakili data pasar yang diperlukan untuk menghitung tingkat return dan resiko pasar pada perusahaan yang tergabung dalam Kompas 100

3. BI rate periode tahun 2010-2014 Return dan resiko saham juga dihitung secara bulanan sehingga dipilihnya $\mathrm{BI}$ rate

Teknik pengumpulan data dalam penelitian ini adalah teknik dokumentasi yaitu dengan cara mengumpulkan data-data sekunder yang tercantum dalam media internet. Perusahaan- 
perusahaan itu disaring dengan kriteria bukan perusahaan baru dan perusahaan yang tidak pernah dikeluarkan dari Kompas 100 selama periode 2010-2014.

Teknik analisis data yang digunakan adalah Model Indeks Tunggal, sedangkan perhitungannya dilakukan dengan menggunakan program Ms.Excel.

Data diolah dengan langkah :

1. Menghitung nilai return realisasi ( $\mathrm{Ri}$ ) masing-masing saham setiap bulannya:

$$
R_{i t}=\frac{P_{t}-P_{t-1}}{P_{t-1}}
$$

$\mathrm{Ri}=$ Return saham ke $\mathrm{i}$

$\mathrm{Pt}=$ Harga saham periode $\mathrm{t}$

Pt-1 = Harga saham periode sebelumnya

Sumber: Jogiyanto (2003: 111) dalam Triharjono, et al (2013)

2. Menghitung return ekspektasi $(\mathrm{E}(\mathrm{R}))$ masing-masing saham dengan rumus

$$
\mathrm{E}(\mathrm{Ri})=\frac{\Sigma R i}{n}
$$

$\mathrm{Ri}=$ Return saham $\mathrm{i}$

$\mathrm{E}(\mathrm{Ri})=$ Tingkat keuntungan yang diharapkan oleh investor $\mathrm{N}=$ Jumlah periode

Sumber: Husnan (2001:51) dalamWibowo, et al (2014)

3. Menghitung return pasar (RM) periode 2010-2014 dengan rumus:

$$
R_{m}=\frac{I H S G_{t}-I H S G_{t-1}}{I H S G_{t-1}}
$$

Sumber : Jogiyanto (2003:232) dalam Sigit Triharjono (2013)

$\mathrm{Rm} \quad=$ Return pasar pada periode tertentu

IHSGt = Indeks harga saham gabungan pada periode tertentu
IHSGt-1 = Indeks harga saham gabungan pada periode sebelumnya

4. Menghitung return ekspektasi pasar $(\mathrm{E}(\mathrm{Rm}))$ dengan rumus:

$$
\mathrm{E}\left(\mathrm{R}_{\mathrm{M}}\right)=\frac{\Sigma R_{M}}{n}
$$

$\mathrm{E}(\mathrm{RM})=$ Tingkat keuntungan pasar yang diharapkan

$\mathrm{RM}=$ Return pasar pada periode tertentu

$\mathrm{N}=$ Jumlah periode

5. Menghitung Standar deviasi

Standar Deviasi

(SD)

digunakan untuk mengukur risiko realized return.

$$
\sigma=\sqrt{\sum_{i=1}^{n} \frac{(R i-E(R i))^{2}}{n-1}} \text { atau } \sigma=\sqrt{\sigma i^{2}}
$$

$\sigma \quad=$ Standar deviasi

$\mathrm{Ri}=$ Return realisasi ke $\mathrm{i}$ saham i

$\mathrm{E}(\mathrm{Ri})=$ rata-rata return realisasi saham $\mathrm{i}$

$\mathrm{N}=$ Jumlah periode return realisasi

6. Menghitung variance dari saham dan pasar.

Variance digunakan untuk mengukur risiko expected return saham i. Variance dapat dihitung dengan cara mengkuadratkan standar deviasi atau menggunakan rumus :

$$
\text { variance }=\sigma i^{2} \text { atau } \sigma i^{2}=\sum_{n-1}^{n} \frac{(R i-E(R i))^{2}}{n-1}
$$

Sumber : Mirah, et al. 2009

$\sigma \mathrm{i}^{2} \quad=$ Variance saham $\mathrm{i}$

$\mathrm{Ri} \quad=$ Return saham $\mathrm{i}$

$\mathrm{E}(\mathrm{Ri})=$ Expected Return saham i

$\mathrm{N} \quad=$ jumlah periode

7. Menghitung kovarian saham dengan pasar yang 
mencerminkan hubungan antara return saham dengan return pasar. Covariance adalah rata-rata penyimpangan masing-masing data, merupakan perbandingan perhitungan realized return saham dengan realized return market.

Rumus yang digunakan adalah:

$$
\begin{array}{ll}
\text { oim }= & (R i-E(R i)) \cdot(R m-E(R m)) \\
\sigma \mathrm{m} & =\text { Kovarian } \\
\mathrm{Ri} & =\text { return saham } \\
\mathrm{E}(\mathrm{Ri}) & =\text { expected return } \\
& \text { saham } \mathrm{i} \\
\mathrm{Rm} & =\text { return pasar } \\
\mathrm{E}(\mathrm{Rm}) & =\text { expected return } \\
& \text { pasar }
\end{array}
$$

8. Menghitung beta dan alpha dengan rumus:

$\beta i=\left(\frac{\sigma i m}{\sigma m}\right) \quad \alpha=\mathrm{E}\left(\mathrm{R}_{1}\right)-\left(\beta \cdot \mathrm{E}\left(\mathrm{R}_{\mathrm{M}}\right)\right)$

Sumber: Tandelilin (2010:132) dalam Wibowo,et al (2014)

9. Menghitung risiko tidak sistematis / variance residual error $\left(\sigma \mathrm{ei}^{2}\right)$

$$
\begin{gathered}
e i=R i-\alpha i-(\beta i . R m) \\
\sigma e i^{2}=\frac{\sum_{i=1}^{n}\left(e i-E(e i)^{2}\right.}{n-1}
\end{gathered}
$$

Sumber: Tandelilin (2010:178) dalam Wibowo, et al (2014)

10. Menentukan tingkat pengembalian bebas resiko (RBr) yang akan menggunakan rata-rata $\mathrm{BI}$ rate periode 2010 2014

11. Menghitung excess return to beta (ERBi) dengan rumus

$$
\mathrm{ERB}_{\mathrm{i}}=\frac{E\left(R_{i}\right)-R_{B R}}{\beta_{i}}
$$

Sumber: Hartono (2014: 430)

$\mathrm{ERBi}=$ Excess return to beta pada sekuritas $\mathrm{i}$

$\mathrm{E}(\mathrm{Ri})=$ Expected return

$\mathrm{RBR}=$ Return bebas resiko

$\mathrm{Bi} \quad=$ beta saham

12. Menyusun peringkat saham berdasarkan ERB tertinggi sampai terendah

13. Menghitung nilai $\mathrm{Ai}$ dan $\mathrm{Bi}$ untuk masing-masing sekuritas ke-i

$$
\mathrm{A}_{\mathrm{i}}=\frac{\left[E\left(R_{i}\right)-R_{b r}\right] \cdot \beta_{i}^{-}}{\sigma_{e i}^{2}} \quad \mathrm{~B}_{\mathrm{i}}=\frac{\beta_{i}^{2}}{\sigma_{e i}{ }^{2}}
$$

$\mathrm{E}$

(Ri) = expected return

$\mathrm{Rbr} \quad=$ return bebas risiko

$\beta \mathrm{i}=$ beta saham $\mathrm{i}$

$\sigma \mathrm{ei}^{2}=$ variance error residual saham

Sumber: Hartono (2014: 431)

14. Menghitung nilai $\mathrm{Ci}$, yaitu nilai C untuk sekuritas ke-i yang dihitung dari akumulasi nilainilai A1 sampai Ai dan nilai-

$$
\mathrm{Ci}=\frac{\sigma m^{2} \sum_{j=1}^{i} \frac{[E(R i)-R b r] \beta i}{\sigma e i^{2}}}{1+\sigma m^{2} \sum_{j=1}^{i} \frac{\beta i^{2}}{\sigma e i^{2}}}
$$

nilai B1 sampai Bi.

Sumber: Hartono (2014: 432)

15. Menentukan unique-cut-off point $\left(\mathrm{C}^{*}\right)$

Nilai $C^{*}$ merupakan nilai $\mathrm{Ci}$ tertinggi pada kelompok saham-saham yang masuk dalam portofolio optimal

16. Menentukan portofolio optimal dengan ukuran $\mathrm{ERBi} \geq \mathrm{C}^{*}$

17. Menghitung proporsi dari masing-masing sekuritas dengan rumus berikut:

$$
\begin{aligned}
& \mathrm{Z}_{\mathrm{i}}=\frac{\beta_{i}}{\sigma_{e i}{ }^{2}}\left(\mathrm{ERB}_{\mathrm{i}}-\mathrm{C}^{*}\right) \\
& \mathrm{W}_{\mathrm{i}}=\frac{Z_{i}}{\sum_{j=1}^{k} Z_{j}}
\end{aligned}
$$


Sumber : Jogiyanto (2010:366367) dalam Dahlan (2015)

18. Menghitung nilai return portofolio dari kombinasi portofolio yang telah terpilih dengan rumus:

$\mathrm{E}(\mathrm{Rp})=\alpha \mathrm{p}+\beta \mathrm{p} . \mathrm{E}(\mathrm{RM})$

$\mathrm{E}(\mathrm{Rp})=$ expected return portofolio

Ap = nilai ekspektasi dari return sekuritas portofolio yang independen terhadap return pasar

$\beta \mathrm{p} \quad=$ beta sekuritas portofolio
$\mathrm{E}(\mathrm{Rm})=$ expected return pasar Sumber: Hartono (2013: 356) dalam Wibowo (2014)

19. Menghitung risiko portofolio atau variance portofolio dari kombinasi portofolio yang telah terpilih dengan rumus: $\sigma \mathrm{p}^{2}=\beta \mathrm{p}^{2} . \sigma \mathrm{M}^{2}$

Sumber: Hartono (2013: 361) dalam Wibowo (2014)

\section{HASIL DAN PEMBAHASAN}

Berdasarkan dari populasi 270 perusahaan yang tergabung ke dalam Indeks Kompas 100 di Bursa Efek Indonesia (BEI) Periode 20102014 , terdapat 44 perusahaan yang memenuhi kriteria untuk digunakan sebagai sampel penelitian.

Tabel 1

Hasil Perhitungan Expected return, Variance, Standar Deviasi dan Kovarian Saham yang menjadi sampel penelitian

\begin{tabular}{|c|c|c|c|c|c|c|}
\hline No & Kode & Perusahaan & $\mathbf{E}(\mathbf{R i})$ & $\begin{array}{c}\text { Variance } \\
\sigma i^{2} \\
\end{array}$ & $\begin{array}{c}\text { Std Deviasi } \\
\sigma i \\
\end{array}$ & $\begin{array}{c}\text { Kovarian } \\
\sigma \mathrm{m} \\
\end{array}$ \\
\hline 1 & ADRO & Adaro Energy Tbk & 0,002502539 & 0,01202692 & 0,10966731 & 0,001571129 \\
\hline 2 & AKRA & $\begin{array}{c}\text { AKR Corporindo } \\
\text { Tbk } \\
\end{array}$ & 0,028141529 & 0,015042358 & 0,12264729 & 0,003604694 \\
\hline 3 & ASRI & $\begin{array}{c}\text { Alam Sutera Realty } \\
\text { Tbk }\end{array}$ & 0,139061877 & 0,810356701 & 0,90019815 & $\begin{array}{c}- \\
0,008557094\end{array}$ \\
\hline 4 & ANTM & $\begin{array}{l}\text { Aneka Tambang } \\
\text { (Persero) Tbk }\end{array}$ & 0,128662191 & 1,435596936 & 1,19816399 & 0,00674568 \\
\hline 5 & AALI & $\begin{array}{c}\text { Astra Agro Lestari } \\
\text { Tbk }\end{array}$ & 0,005080822 & 0,008330405 & 0,09127105 & 0,00064928 \\
\hline 6 & ASII & $\begin{array}{c}\text { Astra International } \\
\text { Tbk } \\
\end{array}$ & 0,015188959 & 0,005018747 & 0,07084312 & 0,002524739 \\
\hline 7 & BBKP & Bank Bukopin Tbk & 0,017867058 & 0,012313006 & 0,11096398 & 0,003468394 \\
\hline 8 & $\mathrm{BBCA}$ & $\begin{array}{c}\text { Bank Central Asia } \\
\text { Tbk }\end{array}$ & 0,018885691 & 0,004407604 & 0,06638979 & 0,002229475 \\
\hline 9 & BDMN & Bank Danamon Tbk & 0,003678345 & 0,00661984 & 0,0813624 & 0,001768089 \\
\hline 10 & BMRI & $\begin{array}{l}\text { Bank Mandiri } \\
\text { (Persero) Tbk }\end{array}$ & 0,017760273 & 0,007333063 & 0,08563331 & 0,003371026 \\
\hline 11 & BBNI & $\begin{array}{c}\text { Bank Negara } \\
\text { Indonesia (Persero) } \\
\text { Tbk } \\
\end{array}$ & 0,023411084 & 0,007513947 & 0,08668303 & 0,002892351 \\
\hline 12 & PNBN & $\begin{array}{c}\text { Bank Pan Indonesia } \\
\text { Tbk }\end{array}$ & 0,012634914 & 0,011593984 & 0,10767536 & 0,002621802 \\
\hline 13 & BBRI & $\begin{array}{c}\text { Bank Rakyat } \\
\text { Indonesia (Persero) } \\
\text { Tbk } \\
\end{array}$ & 0,02276863 & 0,008588689 & 0,09267518 & 0,003334731 \\
\hline 14 & BHIT & $\begin{array}{c}\text { Bhakti Investama } \\
\text { Tbk }\end{array}$ & 0,092285987 & 0,1561848 & 0,39520223 & 0,000910014 \\
\hline
\end{tabular}




\begin{tabular}{|c|c|c|c|c|c|c|}
\hline 15 & BSDE & $\begin{array}{c}\text { Bumi Serpong } \\
\text { Damai Tbk }\end{array}$ & 0,021690233 & 0,017392722 & 0,13188147 & 0,003664433 \\
\hline 16 & CPIN & $\begin{array}{c}\text { Charoen Pokhpand } \\
\text { Tbk }\end{array}$ & 0,045978823 & 0,022295592 & 0,14931708 & 0,004368135 \\
\hline 17 & CTRA & $\begin{array}{c}\text { Ciputra } \\
\text { Development Tbk }\end{array}$ & 0,037847838 & 0,020764506 & 0,14409894 & 0,003693172 \\
\hline 18 & ENRG & $\begin{array}{l}\text { Energi Mega } \\
\text { Persada Tbk }\end{array}$ & 0,000034669 & 0,022150272 & 0,14882967 & 0,004152878 \\
\hline 19 & GJTL & Gajah Tunggal Tbk & 0,02945794 & 0,019578244 & 0,13992228 & 0,003133741 \\
\hline 20 & BMTR & $\begin{array}{c}\text { Global Mediacom } \\
\text { Tbk }\end{array}$ & 0,040448979 & 0,017108961 & 0,13080123 & 0,002124087 \\
\hline 21 & GGRM & Gudang Garam Tbk & 0,021441071 & 0,008521489 & 0,09231191 & 0,001122518 \\
\hline 22 & SMCB & $\begin{array}{c}\text { Holcim Indonesia } \\
\text { Tbk } \\
\end{array}$ & 0,010598613 & 0,009752768 & 0,0987561 & 0,002950812 \\
\hline 23 & INDY & Indika Energy Tbk & $\begin{array}{c}- \\
0,015696622\end{array}$ & 0,017854299 & 0,13361998 & 0,003728797 \\
\hline 24 & ITMG & $\begin{array}{c}\text { Indo Tambangraya } \\
\text { Megah Tbk }\end{array}$ & $\begin{array}{c}- \\
0,007006897\end{array}$ & 0,010352624 & 0,10174785 & 0,001388769 \\
\hline 25 & INTP & $\begin{array}{c}\text { Indocement } \\
\text { Tunggal Prakasa } \\
\text { Tbk } \\
\end{array}$ & 0,013217087 & 0,006524115 & 0,08077199 & 0,001960931 \\
\hline 26 & INDF & $\begin{array}{l}\text { Indofood Sukses } \\
\text { Makmur Tbk }\end{array}$ & 0,013029694 & 0,004696827 & 0,0685334 & 0,001992613 \\
\hline 27 & ISAT & Indosat Tbk & 0,001473625 & 0,008320134 & 0,09121477 & 0,002531021 \\
\hline 28 & JSMR & $\begin{array}{c}\text { Jasa Marga } \\
\text { (Persero) Tbk }\end{array}$ & 0,025358286 & 0,005275603 & 0,07263335 & 0,001646921 \\
\hline 29 & KLBF & Kalbe Farma Tbk & 0,022630238 & 0,018709972 & 0,1367844 & 0,001737417 \\
\hline 30 & KIJA & $\begin{array}{c}\text { Kawasan Industri } \\
\text { Jababeka Tbk }\end{array}$ & 0,023681227 & 0,018062147 & 0,13439549 & 0,003349485 \\
\hline 31 & LPKR & $\begin{array}{c}\text { Lippo Karawaci } \\
\text { Tbk } \\
\end{array}$ & 0,02060334 & 0,014290565 & 0,11954315 & 0,002867586 \\
\hline 32 & MEDC & $\begin{array}{c}\text { Medco Energi } \\
\text { International Tbk }\end{array}$ & 0,011383641 & 0,008506844 & 0,09223255 & 0,000909041 \\
\hline 33 & $\mathrm{MNCN}$ & $\begin{array}{c}\text { Media Nusantara } \\
\text { Citra Tbk }\end{array}$ & 0,052572672 & 0,023203345 & 0,15232644 & 0,003312305 \\
\hline 34 & PNLF & Panin Life Tbk & 0,020361262 & 0,01583058 & 0,12581963 & 0,003836661 \\
\hline 35 & PGAS & $\begin{array}{c}\text { Perusahaan Gas } \\
\text { Negara (Persero) } \\
\text { Tbk } \\
\end{array}$ & 0,010269432 & 0,006104452 & 0,07813099 & 0,001328194 \\
\hline 36 & LSIP & $\begin{array}{c}\text { PP London } \\
\text { Sumatera Plantation } \\
\text { Tbk }\end{array}$ & $\begin{array}{c}- \\
0,002271755\end{array}$ & 0,026986713 & 0,16427633 & 0,001106656 \\
\hline 37 & SMGR & $\begin{array}{l}\text { Semen Indonesia } \\
\text { (Persero) Tbk }\end{array}$ & 0,015842616 & 0,006247338 & 0,0790401 & 0,002676377 \\
\hline 38 & BKSL & Sentul City Tbk & 0,015306311 & 0,033232344 & 0,18229741 & 0,003556716 \\
\hline 39 & SMRA & $\begin{array}{c}\text { Summarecon } \\
\text { Agung Tbk }\end{array}$ & 0,027476793 & 0,020826364 & 0,14431342 & 0,0050397 \\
\hline 40 & PTBA & $\begin{array}{c}\text { Tambang Batubara } \\
\text { Bukit Asam } \\
\text { (Persero) Tbk } \\
\end{array}$ & 0,000803163 & 0,009063423 & 0,09520201 & 0,002048381 \\
\hline 41 & TLKM & $\begin{array}{c}\text { Telekomunikasi } \\
\text { Indonesia (Persero) } \\
\text { Tbk }\end{array}$ & 0,003475719 & 0,015185831 & 0,12323081 & 0,002393801 \\
\hline
\end{tabular}




\begin{tabular}{|c|c|c|c|c|c|c|}
\hline 42 & TINS & $\begin{array}{c}\text { Timah (Persero) } \\
\text { Tbk }\end{array}$ & 0,000697046 & 0,01516611 & 0,12315076 & 0,002709421 \\
\hline 43 & UNVR & $\begin{array}{c}\text { Unilever Indonesia } \\
\text { Tbk }\end{array}$ & 0,020356984 & 0,004709366 & 0,06862482 & 0,000556383 \\
\hline 44 & UNTR & $\begin{array}{c}\text { United Tractors } \\
\text { Tbk }\end{array}$ & 0,005852418 & 0,006562188 & 0,08100734 & 0,001996734 \\
\hline \multicolumn{4}{|c|}{$\begin{array}{l}\text { expected return ada } 7 \text { saham yang } \\
\text { mempunyai nilai return negatif, yaitu } \\
\text { saham ADRO, INDY, ITMG, LSIP, } \\
\text { PTBA, TLKM, dan TINS. Saham- } \\
\text { saham yang bernilai negatif maka }\end{array}$} & \multicolumn{3}{|c|}{ 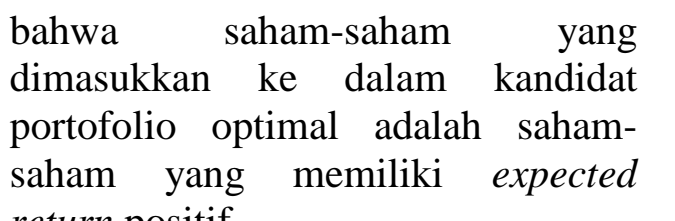 } \\
\hline
\end{tabular}

Tabel 2

Expected Return Pasar, Standar Deviasi, Variance IHSG Kompas 100 periode 2010-2014

\begin{tabular}{|c|c|}
\hline & $\begin{array}{c}\text { IHSG Kompas 100 } \\
(\mathbf{R m})\end{array}$ \\
\hline $\mathrm{E}(\mathrm{Rm})$ & 0,0115875237 \\
\hline $\begin{array}{c}\text { Standar } \\
\text { Deviasi }\end{array}$ & 0,046995629 \\
\hline Variance & 0,0022460228 \\
\hline
\end{tabular}

Expected return pasar yang bernilai positif ini membuktikan bahwa investasi di pasar modal memberikan return bagi investor.

\section{Hasil Perhitungan Return Bebas Risiko}

Nominal $32,875 \%$ merupakan BI rate per annual (per tahun) yang didapat dari jumlah BI rate tiap bulan selama 5 tahun dibagi 12 . Sedangkan 0,54\% diperoleh dari BI rate per tahun dibagi dengan 60 bulan (periode penelitian 5 tahun), maka diperoleh return bebas risiko per bulan sebesar $0,54 \%$ atau 0,0054 .

\section{Hasil Perhitungan Alpha, Beta,} Variance Error Residual dan Erb

$$
\text { Alpha bervariatif, ada }
$$
perusahaan yang mempunyai nilai alpha negatif dan positif. Alpha adalah nilai expected return saham yang independen terhadap return pasar. Apabila ada perubahan return pasar yang berupa peningkatan atau penurunan maka tidak berpengaruh terhadap return saham individual. Perusahaan yang memiliki beta tertinggi yaitu Aneka Tambang (persero) Tbk sebesar 3,077. Hal ini dapat diartikan apabila ada return pasar meningkat satu satuan, maka akan ada peningkatan return saham Aneka Tambang (persero) Tbk sebesar 3,077 satuan. Berdasarkan dari perhitungan excess return to beta dari 37 saham perusahaan, diperoleh saham dengan ERB tertinggi yaitu Unilever Indoneesia Tbk (UNVR) sebesar 0,059. Sedangkan saham perusahaan dengan ERB terendah yaitu Bhakti Investama Tbk (BHIT) sebesar0,204 . Portofolio optimal berisikan kumpulan saham-saham yang mempunyai rasio ERB yang tinggi. Penentuan tinggi atau rendahnya 
ERB ini berdasarkan titik pembatas cut off point $\left(\mathrm{C}^{*}\right)$.

\section{Menentukan Unique Cut-Off Point}

Perhitungan nilai unique cut-off point $\left(\mathrm{C}^{*}\right)$ pada penelitian ini sebesar 0,0094897 dan nilai ERB 0,0198 yaitu perusahaan Ciputra Development Tbk (CTRA). Pada model indeks tunggal langkahlangkah yang dilakukan yaitu mengurutkan saham-saham yang mempunyai ERB tertinggi ke terendah. Penelitian ini terdapat 13 saham yang menjadi kandidat portofolio optimal yang diurutkan dari nilai ERB tertinggi sampai terendah.

\section{Tabel 3}

Perbandingan Nilai ERB dengan Cut-Off Rate masing-masing Saham

\begin{tabular}{|c|c|c|c|c|c|}
\hline No & Kode & Perusahaan & ERb & & Ci \\
\hline 1 & UNVR & Unilever Indonesia Tbk & 0,0590241 & $>$ & 0,0007432 \\
\hline 2 & ANTM & $\begin{array}{c}\text { Aneka Tambang (Persero) } \\
\text { Tbk }\end{array}$ & 0,0400343 & $>$ & 0,0003511 \\
\hline 3 & BMTR & Global Mediacom Tbk & 0,0369354 & $>$ & 0,003119 \\
\hline 4 & GGRM & Gudang Garam Tbk & 0,0319926 & $>$ & 0,0016316 \\
\hline 5 & MNCN & Media Nusantara Citra Tbk & 0,0314501 & $>$ & 0,0064267 \\
\hline 6 & JSMR & Jasa Marga (Persero) Tbk & 0,0264968 & $>$ & 0,0072375 \\
\hline 7 & KLBF & Kalbe Farma Tbk & 0,0222706 & $>$ & 0,0017656 \\
\hline 8 & CPIN & Charoen Pokhpand Tbk & 0,0203682 & $>$ & 0,000046 \\
\hline 9 & CTRA & Ciputra Development Tbk & 0,0197993 & $>$ & $\mathbf{0 , 0 0 9 4 8 9 7}$ \\
\hline 10 & GJTL & Gajah Tunggal Tbk & 0,0169425 & $>$ & 0,0068242 \\
\hline & & Medco Energi International & & & \\
11 & MEDC & Tbk & 0,0142028 & $>$ & 0,001088 \\
\hline 12 & KIJA & Kawasan Industri Jababeka & & & \multirow{2}{*}{ Tbk } \\
\hline 13 & LPKR & Lippo Karawaci Tbk & 0,0119629 & $>$ & 0,0091631 \\
\hline
\end{tabular}

Hasil Perhitungan Skala Tertimbang dan Proporsi Dana

Komposisi proporsi dana (Wi) untuk membentuk portofolio yang optimal: UNVR sebesar 0,002372 atau $0,2372 \%$. ANTM sebesar 0,000058 atau $0,0058 \%$. BMTR sebesar 0,001500 atau 0,15 $\%$. GGRM sebesar 0,001227 atau $0,122657 \%$. MNCN sebesar 0,001572 atau $0,1572 \%$. JSMR sebesar 0,002749 atau 0,2749\%. KLBF sebesar 0,000493 atau 0,0493 $\%$. CPIN sebesar 0,987719 atau $98,771899 \%$. CTRA sebesar 0,001009 atau 0,1009 \%. GJTL sebesar 0,000608 atau 0,0608 \%.
MEDC sebesar 0,000209 atau 0,0209 $\%$. KIJA sebesar 0,000253 atau $0,0253 \%$. LPKR sebesar 0,000232 atau $0,0232 \%$.

\section{Hasil Perhitungan Return Portofolio}

Return portofolio yang dihitung dari 13 saham yang menjadi kandidat portofolio optimal adalah $4,74 \%$. Return portofolio tersebut cukup menjanjikan karena return portofolio tersebut di atas tingkat pengembalian pasar $\mathrm{E}(\mathrm{Rm})$ sebesar $1,16 \%$ dan di atas tingkat return bebas risiko sebesar $0,54 \%$ per bulan. 
PENUTUP

Kesimpulan

Berdasarkan analisis dan pembahasan maka dapat ditarik kesimpulan sebagai berikut:

1. Terdapat 13 saham yang memenuhi kriteria pilihan saham untuk berinvestasi yaitu UNVR, ANTM, BMTR, GGRM, MNCN, JSMR, KLBF, CPIN, CTRA, GJTL, MEDC, KIJA, LPKR

2. Besarnya komposisi proporsi dana yang layak diinvestasikan pada 13 saham tersebut adalah

UNVR (Unilever Indonesia Tbk) sebesar 0,2372039\%

\begin{tabular}{lrr} 
ANTM & (Aneka & $\begin{array}{r}\text { Tambang } \\
\text { (persero) }\end{array}$ \\
$0,005764 \%$ & Tbk) & sebesar \\
\hline & &
\end{tabular}

BMTR (Global Mediacom Tbk) sebesar 0,1499779\%

GGRM (Gudang Garam Tbk) sebesar 0,1226567\%

MNCN (Media Nusantara Citra

Tbk) sebesar $0,1571756 \%$

JSMR (Jasa Marga Persero Tbk) sebesar 0,2749157\%

KLBF (Kalbe Farma Tbk) sebesar 0,0493033\%

CPIN (Charoen Pokphand Indonesia Tbk) sebesar 98,771899\%

CTRA (Ciputra Development Tbk) sebesar 0,1009368\%

GJTL (Gajah Tunggal Tbk) sebesar 0,0607808\%

MEDC (Media Energi International Tbk) sebesar 0,0209188\%

KIJA (Kawasan Industri Jababeka Tbk) sebesar $0,0253161 \%$

LPKR (Lippo Karawaci Tbk) sebesar 0,0231518\%

3. Saham-saham pilihan tersebut diharapkan memiliki tingkat pengembalian sebesar $4,74 \%$ per bulan dan risiko yang harus dihadapi dari hasil berinvestasi pada portofolio tersebut adalah sebesar 0,0019683\%. Risiko yang diperoleh setelah pembentukan portofolio optimal ini lebih kecil dibandingkan dengan berinvestasi dengan saham individual.

\section{Saran}

Setelah melakukan analisis dan pembahasan terhadap masalah yang terjadi, maka saran-saran yang dapat diberikan adalah sebagai berikut :

1. Data harga saham dan IHSG Kompas 100 yang digunakan adalah harga closing price bulanan sehingga kurang mencerminkan keadaan pada harian pengamatan, dimana fluktuasi harga saham terjadi pada setiap harinya. Penelitian selanjutnya sebaiknya menggunakan harga closing price harian karena dapat memberikan hasil yang lebih baik.

2. Investor dapat mengalokasikan dananya untuk berinvestasi pada 13 saham tersebut.

3. Bagi perusahaan yang sahamnya belum memenuhi syarat untuk menjadi pilihan berinvestasi, dapat melakukan perbaikan kinerja perusahaannya agar sahamnya meningkat.

\section{DAFTAR PUSTAKA}

Dahlan, Suyudi. Et al. 2015. Penggunaan Single Index Model dalam Analisis Portofolio untuk Meminimumkan Resiko Bagi Investor di Pasar Modal (Studi pada Perusahaan LQ45 di BEI 2010-2012). Jurnal 
Administrasi Bisnis (JAB)

Universitas Brawijaya, Vol.

6, No. 2, Desember 2013.

Hartono, Jogiyanto. 2014. Teori

Portofolio dan Analisis

Investasi. Edisi Kesembilan.

Yogyakarta: BPFE-

Yogyakarta.

Hamdani, Ardi Sanjaya. 2015. Pembentukan Portofolio Optimal pada Indeks Kompas 100 Periode 20132014.Jurnal Ilmiah

Mahasiswa Universitas Surabaya, Vol. 4, No. 2

Ibrahim. 2009. Reaksi Pasar Terhadap Pengumuman Kenaikan dividen Perusahaan Manufaktur Indonesia. Kajian Akuntansi, UPN veteran, Volume 4, Nomor 2, Desember 2009: 137-146

Mirah, Et al. 2009. Analisis Model Indeks Tunggal Portofolio Saham di Bursa Efek Indonesia (BEI) Periode 2009-2011.

Mohamad, Samsul. 2006. Pasar Modal dan Manajemen Portofolio. Surabaya: Penerbit Erlangga.

Ratnasari, Linda. 2015. Perbandingan Return Saham Kompas 100 Menggunakan Model Indeks Tunggal dan Model Random. Jurnal Ilmu dan Riset Manajemen STIESIA Volume 4, Nomor 4, April 2015.
Suharli, Michelle. 2005. Studi Empiris Terhadap Dua Faktor yang Mempengaruhi Return Saham pada Industri Food and Baverages di Bursa Efek Indonesia. Jurnal akuntansi \& Keuangan Universitas Kristen PETRA, vol 7, no. 2, November 2005: 99- 116

Sugiyono. 2009. Metode Penelitian Pendidikan (Pendekatan Kuantitatif, Kualitatif, dan $R \& D)$. Bandung : Alfabeta.

Tandelilin, Eduardus. 2010. Portofolio dan Investasi. Edisi Pertama. Yogyakarta: Kanisius.

Triharjono, Sigit. 2013. Single Index Model Sebagai Alat Analisis Optimalisasi Portofolio Investasi Saham (Studi pada Kelompok Saham LQ45 di BEI 20092011). Jurnal Ilmu Manajemen \& Bisnis Universitas Pendidikan Indonesia, Vol. 04, No. 01, Maret 2013.

Wibowo, Windy Martya. Et al. 2014. Penerapan Model Indeks Tunggal Untuk Menetapkan Komposisi Portofolio Optimal pada Saham LQ45 yang Listing di BEI 2010-2012. Jurnal Administrasi Bisnis (JAB) Universitas Brawijaya Vol. 9, No. 1, April 2014. 